\title{
Non-conventional therapies for analgesia
}

\author{
Terapias não convencionais para analgesia \\ Terapias no convencionales para la analgesia
}

Received: 10/06/2021 | Reviewed: 10/11/2021 | Accept: 11/03/2021| Published: 11/05/2021

\author{
Mariana Papa Pellizoni \\ ORCID: https://orcid.org/0000-0001-5466-3297 \\ Faculdade São Leopoldo Mandic, Brasil \\ E-mail: marianapapap@outlook.com \\ Rafael Faccio \\ ORCID: https://orcid.org/0000-0001-8599-0370 \\ Faculdade São Leopoldo Mandic, Brasil \\ E-mail: rrfaccio@gmail.com \\ Cláudio Roberto Pacheco Jodas \\ ORCID: https://orcid.org/0000-0002-9750-2714 \\ Faculdade São Leopoldo Mandic, Brasil \\ E-mail: cjodas@yahoo.com.br \\ Ricardo Grilo \\ ORCID: https://orcid.org/0000-0002-8096-738X \\ Faculdade São Leopoldo Mandic, Brasil \\ E-mail: doutorgrillo@uol.com.br \\ Rubens Gonçalves Teixeira \\ ORCID: https://orcid.org/0000-0003-0814-0940 \\ Faculdade São Leopoldo Mandic, Brasil \\ E-mail: rgte@terra.com.br \\ Marilia de Oliveira Coelho Dutra Leal \\ ORCID: https://orcid.org/0000-0003-1164-9983 \\ Faculdade de Odontologia de Piracicaba, Brasil \\ E-mail: marilialeal@hotmail.com
}

\begin{abstract}
Purpose: Third molar surgery is a quite common procedure. Some patients experience pain associated with this situation. The aim of this article aims to discuss non-conventional therapies for the management of postoperative pain associated with third molar surgery. Methods: An extensive literature search was conducted with the keywords "third molar" + "pain" and all articles that excluded already established drugs as analgesics, anti-inflammatories, or therapies such as laser therapy and ozone therapy whereas non-conventional drugs and therapies were retained. Results: The article rated bromelain, honey, hyaluronic acid, nicotine patches, Kinesio tape, TENS, anticonvulsants, curcumin, and melatonin. Some therapies are efficient and safe, while others have not shown promising results. Conclusions: Bromelain and Kinesio tape are considered the most effective non-conventional therapies for controlling postoperative pain, and even with few studies on them, they are therapies with promising results.
\end{abstract}

Keywords: Third molar; Pain; Complementary therapies.

\section{Resumo}

Objetivo: a cirurgia do terceiro molar é um procedimento muito comum. Alguns pacientes sentem dor associada a essa situação. O objetivo deste artigo é discutir as terapias não convencionais para o manejo da dor pós-operatória associada à cirurgia de terceiros molares. Métodos: Uma extensa pesquisa bibliográfica foi realizada com as palavras-chave "terceiro molar" + "dor" e todos os artigos que excluíam drogas já estabelecidas como analgésicos, antiinflamatórios ou terapias como terapia a laser e terapia de ozônio, considerando drogas não convencionais e terapias foram mantidas. Resultados: O artigo avaliou bromelaína, mel, ácido hialurônico, adesivos de nicotina, fita Kinesio, TENS, anticonvulsivantes, curcumina e melatonina. Algumas terapias são eficientes e seguras, enquanto outras não apresentam resultados promissores. Conclusões: Bromelaína e Kinesio tape são consideradas as terapias não convencionais mais eficazes para o controle da dor pós-operatória e, mesmo com poucos estudos sobre elas, são terapias com resultados promissores.

Palavras-chave: Terceiro molar; Dor; Terapias complementares.

\section{Resumem}

Objetivo: La cirugía del tercer molar es un procedimiento muy común. Algunos pacientes experimentan dolor asociado con esta situación. El objetivo de este artículo tiene como objetivo discutir las terapias no convencionales para el manejo del dolor postoperatorio asociado a la cirugía del tercer molar. Métodos: Se realizó una búsqueda bibliográfica extensa con las palabras clave "tercer molar" + "dolor" y todos los artículos que excluían fármacos ya establecidos como 
analgésicos, antiinflamatorios o terapias como la terapia láser y la ozonoterapia mientras que los fármacos no convencionales y se mantuvieron las terapias. Resultados: El artículo calificó bromelina, miel, ácido hialurónico, parches de nicotina, cinta Kinesio, TENS, anticonvulsivos, curcumina y melatonina. Algunas terapias son eficientes y seguras, mientras que otras no han mostrado resultados prometedores. Conclusiones: La bromelina y la cinta Kinesio se consideran las terapias no convencionales más efectivas para el control del dolor postoperatorio, e incluso con pocos estudios al respecto, son terapias con resultados prometedores.

Palabras clave: Tercero molar; Dolor; Terapias complementarias.

\section{Introduction}

Oral operations represent a painful postoperative phase with relative frequency, especially extractions of third molars. Several maneuvers are used to make this postoperative period as mild as rest, avoiding sun exposure or excessive heat, holding your head high, and using cold compresses, among others.

Drug therapy plays a vital role in postoperative analgesia, and several drugs can be used in three different pharmacological classes, analgesics, NSAIDs, and corticosteroids. When using one or more of these drugs, the analgesic effectiveness is excellent in most cases, be it with the medication in the pre- or post-operative phase. Among these drugs, we can mention dipyrone, codeine, dexamethasone, diclofenac, ketoprofen, among others. Although they are not suitable for treating postoperative pain, other drugs, such as anxiolytics and muscle relaxants, may be effective in some cases.

Not all patients feel completely pain-free, and some professionals are trying to use other therapies and other drugs to keep patients at an increasingly efficient levels of analgesia. The combination of these unconventional therapies with some more traditional analgesics can be a very efficient solution for post-operative in oral surgery. The purpose of this article is to report on drugs or other non-conventional therapeutic modalities that help control of postoperative pain during oral surgery.

\section{Methodology}

A literature review was conducted in the PubMed database with the keywords "analgesia" + "third molar" in the last ten years resulting in 346 articles (01/18/2021) (Estrela, 2018). Only articles in English were included. All articles that used systemic drugs already established as analgesics, corticosteroids, anesthetics, anxiolytics, and NSAIDs were excluded, as well as nonmedicated therapies already established, such as laser therapy and ozone therapy. The comparative articles between any of these drugs with any therapy or non-conventional medication were maintained. Only clinical trials in humans have been included. The search for the articles was manual, initially by the title, then by reading the abstract. Only clinical trials were maintained. A total of 46 articles were selected.

With the name of the medication or unconventional therapy, a new search was performed with the keywords "specific medication or unconventional therapy" + "third molar". After reading the articles, 34 were selected, all of which were maintained, even those that did not show any superiority to the drugs and therapies traditionally used to report the efficiency of nonconventional therapies and those that do not show promising results.

\section{Results}

The effectiveness of oral bromelain (single daily dose of 4 x 250mg) was compared with that of diclofenac sodium (4 x $25 \mathrm{mg}$ ) in terms of pain, trismus, edema, and quality of life after impacted third molar surgery, which proved to be an effective therapy and effect compared to diclofenac (Isola et al, 2019). This randomized, double-blind, placebo-controlled study enrolled 45 participants. Bromelain was taken one day before surgery and was continued for another an additional four days. The effectiveness of bromelain was also compared with that of ibuprofen (Isola et al, 2019), dexamethasone (Ghensi et al, 2017), dipyrone (Ordesi et al, 2014). Other studies used bromelain for pain control with some variations in the dosage used 1,000 to 4,500 FIP (Bormann et al, 2016), 40mg every six hours (Ghensi et al, 2017), 50mg 8/8 h for one to three days (de la Barrera-Núñez et 
al, 2014), 50mg 12/12h for five days (Isola et al, 2019; Ordesi et al, 2014). Bromelain is effective at treating postoperative pain up to seven days after surgery, but no significant difference was seen with trismus. Only three of the six studies that were part of this review report any relevant effects in the control and bromelain groups (Ordesi et al, 2014; de la Barrera-Núñez et al, 2014) or statistically insignificant differences (Bormann et al, 2016). The other three articles showed greater effectiveness than the control group with a moderate effect on pain control, trismus, and postoperative edema (Isola et al, 2019; Ghensi et al, 2017; Majid \& AlMashhadani, 2014).

Other proteolytic enzymes were investigated, more specifically serratiopeptidase (Murugesan et al, 2012) and a combination based on two proteases (trypsin 48mg, bromelain 90mg) and a bioflavonoid (rut side 100mg) called SET (systemic enzyme therapy) (Gandhewar et al, 2020). Serratiopeptidase was compared to dexamethasone in 110 patients, while SET was compared to diclofenac in 200 patients.

In a randomized, triple-blinded clinical trial, nicotine patches were used in 20 patients. They were effective in controlling pain, edema, and trismus. The number of pain medications used was inferior, and patient satisfaction was significantly higher, even with some nausea in the nicotine patch group. Nicotine patches were effective in controlling postoperative third molar pain, edema, and trismos (Landim et al, 2020).

The largest number of articles found related to the use of platelet concentrates in third molar surgeries, three related to platelet-rich plasma (PRP) and 12 related to platelet-rich fibrin (PRF). The focus of the articles was on evaluating the timing of new bone formation when used in platelet concentrates. However, some articles also assessed postoperative pain, edema and trismus and reported efficient control of these elements in the postoperative period with PRP (Célio-Mariano et al, 2012; Ogundipe et al, 2012). Some studies have looked at pain, edema, and trismus control with PRF, with new bone formation in the background (Ogundipe et al, 2012). Others compared using to two different platelet concentrates that do not show whether they are effective in controlling a control group or other drugs (Caymaz \& Uyanik 2019; Afat et al, 2018).

Drugs used to treat other pathologies were also rated as anticonvulsants. Administration of $150 \mathrm{mg}$ of pregabalin in conjunction with ibuprofen was found to be effective in controlling postoperative pain, with side effects like those of other analgesic drugs (Degirmenci \& Yalcin, 2019). Taking 75mg of pregabalin in combination with paracetamol one hour before the operation also showed a reduction in side effects (Olmedo-Gaya et al, 2016). However, there have been reports that pregabalina at the same dosage $(75 \mathrm{mg})$ is more noticeable in the postoperative than that for pain prophylaxis (Cheung et al, 2012).

Some drugs have been used as analgesics, but the literature on them is sparse. Among these drugs, we can mention ascorbic acid (Chaitanya et al, 2019), curcumin (Maulina et al, 2018), Manuka honey (Al-Khanati \& Al-Moudallal 2019), hyaluronic acid (Yilmaz et al 2017), and green tea (Eshghpour et al, 2013).

Four studies examined the effectiveness of Kinesio tape in operations on the third molar. Despite the difficulty of conducting a study with a placebo group, other tapes with the same appearance can be used, which generates some studies with a lower risk of bias (Tatli et al, 2020; da Rocha Heras et al, 2020). Three studies examined 60 patients (Tatli et al, 2020; Yurttutan et al, 2020; Gözlüklü et al, 2020) and one evaluated only 13 patients (da Rocha Heras et al, 2020). There are some variations in the technique of installing Kinesio tapes. One study examined two different techniques, the most efficient of which is for postoperative third molar surgery (Gözlüklü et al, 2020). The pain assessment was carried out with the Visual Pain Scale (VAS) (Tatli et al, 2020; da Rocha Heras et al, 2020; Yurttutan et al, 2020; Gözlüklü et al, 2020) and the edema with the TodorovicMarkovic scale da Rocha Heras et al, 2020), digital measurement with the 3dMD Face System (3dMD, Atlanta, GA) (Gözlüklü et al, 2020) or linear measurements with a compass (Tatli et al, 2020) or a flexible tape (Yurttutan et al, 2020). The tapes were installed by a unique professional who was experienced and trained in installing Kinesio Tape on all publications.

Transcutaneous electrical nerve stimulation (Çebi, 2019; Oteri et al, 2018) has also been found as a further non-drug pain therapy. 


\section{Discussion}

A major mistake found in many articles was that many did not provide the position and time of surgery for the third molars, two factors of paramount importance in pain, trismus, and postoperative edema.

\section{Bromelain}

Bromelain is a compound of proteolytic enzymes obtained from pineapple, Ananas comosus, a fruit that originally comes from the American continent and is common in tropical countries such as Brazil, Costa Rica, Thailand, and the Philippines, the leading world producers. In addition to its function as a proteolytic enzyme, some studies have shown beneficial properties with orally administered bromelain, such as anti-inflammatory and analgesic properties (Maurer, 20001). Bromelain in a daily oral dose of 4 x $250 \mathrm{mg}$ taken one day before surgery has a significant reduction in pain and trismus and increases in quality of life, comparable to and an excellent alternative to diclofenac sodium (Majid). Some articles give bromelain moderate relief from discomfort during third molar operations (Isola et al, 2019; Ghensi et al, 2017; Bormann et al, 2016; Majid \& Al-Mashhadani, 2014). The article that evaluated the largest number of patients, 136 (Bormann et al, 2016), reports the apparent effectiveness of bromelain in relation to the control group. Four studies were double-blind, and most of them, three, reported that bromelain's effectiveness was superior to that of the control group (Isola et al, 2019; Bormann et al, 2016; Majid \& Al-Mashhadani, 2014). Bromelain is effective in controlling post-operative pain and edema of the third molar. However, there is still no standardization of the ideal dose and dosage as each study evaluated used a different one, which makes it difficult to use. There may be synergies between NSAIDs and bromelain that can help control postoperative pain and edema (Ghensi et al, 2017).

The other proteolytic enzymes studied, both serratiopeptidase (Murugesan et al, 2012) and SET (trypsin 48mg, bromelain 90mg, and rut side 100mg) (Gandhewar et al, 2020), showed no efficacy when compared to drugs routinely used to control postoperative pain during third molar operations can be used.

\section{Platelet-rich Fibrin/Platelet Rich Plasma}

Platelet-Rich Fibrin (PRF) and Platelet-Rich Plasma (PRP) are active ingredients obtained by centrifuging the patient's blood. Rich in growth factors, using these substances, accelerate chemotaxis, angiogenesis, and collagen synthesis, and accelerate the repair of damaged tissue (Oyama et al, 2004).

Only one article evaluated the effectiveness of PRP specifically in controlling postoperative pain, edema, and trismos (Ogundipe et al, 2012), and confirmed that the pain measured with VAS was inferior to that of the control group. In contrast, trismus and edema were lower but with a statistically insignificant difference. The study also confirmed the speeding up of the repair of the socket.

In some articles, there was an efficient control with PRF for the items pain, edema, trismus, and bone repair accelerator (Zahid \& Nadershah, 2019; Yüce \& Kömerik, 2019; Kapse et al, 2019; Daugela et al, 2018; Kumar et al, 2015). However, some studies reported no significant effect in controlling pain, edema, and postoperative trismos (Torul et al, 2020; Ritto et al, 2019; Asutay et al, 2017) although the acceleration of tissue repair in the region is evident. The study with the largest number of patients (75) is part of this list (Torul et al, 2020). There is also a report of edema improvement with no effectiveness in reducing trismus and pain (Afat et al, 2018; Ozgul et al, 2015). The articles that rated the effectiveness of platelet concentrates in controlling of postoperative pain in third molar surgery were the ones that presented the most significant amount of risk of bias. The small number of patients studied (Zahid \& Nadershah, 2019) and the lack of an adequate placebo control group were some of them (Caymaz \& Uyanik 2019; Afat et al, 2018). Although several studies on platelet concentrates on third molar surgery, the vast majority have been about socket healing, edema, and pain. Few articles are specific to pain management only. 


\section{Anticonvulsants}

Pregabalin is an analog of GABA that binds to calcium channels and reduces the release of several neurotransmitters, thereby blocking the development of hyperalgesia and central sensitivity. It is used as an antispasmodic drug and to treat peripheral pain, anxiety, and fibromyalgia. In the literature it is shown that, despite the small number of articles, both at $150 \mathrm{mg}$ (Degirmenci \& Yalcin, 2019) and at doses less than 75mg (Olmedo-Gaya et al, 2016 and Cheung et al, 2012) it is useful in the prophylaxis and treatment of pain resulting from third molar surgery. Although no side effects were elevated risk, it was widespread and affected around half of the patients taking this drug (Degirmenci \& Yalcin, 2019; Olmedo-Gaya et al, 2016), which was not reported in another study with $75 \mathrm{mg}$ of pregabalin, with a low incidence of side effects (Cheung et al, 2012).

Another anticonvulsant medication evaluated was lamotrigine, and only one article was found that examined 100 adult patients. It was used preoperatively at a single oral dose of $200 \mathrm{mg}$, but it was not effective in reducing pain during third molar surgery (Modanloo et al, 2018). No study of gabapentin in humans for the treatment of pain after tooth extraction has been found. A pregabalin-like drug is also used to treat peripheral neuropathies.

\section{Kinesio tape}

The Kinesio tape or elastic-therapeutic bandage, was developed in 1973 by the Japanese chiropractor Kenzo Kase, originally created and used in sports medicine to reduce muscle and joint damage. They consist of an elastic polymer wrapped with cotton fibers, are latex-free and are activated by body temperature (Artioli \& Bertolini, 2014). The tapes regulate the lymph and blood flow and divert local congestion of synovial fluid and blood (Kase et al, 2003).

The use of Kinesio Tapes is an effective method to relieve pain, edema, and trismus in the postoperative phase after operations on the third molar (Tatli et al, 2020; da Rocha Heras et al, 2020). The placebo group with edema control bands did not have the same effect with a significant decrease in effectiveness (Tatli et al, 2020). The reduction in edema and pain intensity was found to be so efficient that many patients had no pain or edema 120 hours after the operation (da Rocha Heras et al, 2020).

All studies unanimously confirmed the effectiveness of Kinesio Tape in reducing pain and postoperative edema during third molar operations (Tatli et al, 2020; da Rocha Heras et al, 2020; Yurttutan et al, 2020; Gözlüklü et al, 2020) as it is a more economical therapy, less traumatic, and free of side effects (Yurttutan et al, 2020).

\section{Other drugs}

Honey has been used as a topical antibiotic and wound healing agent due to hydrogen peroxide for centuries. Manuka honey from the Manuka flower (Leptospermum scoparium), a plant from Oceania, contains hydrogen peroxide, also rich in methylglyoxal, a substance with a proven bactericidal effect (Obossou et al, 2021). Manuka honey is more consistent than other types of honey and was added directly to the pan after the operation (Al-Khanati \& Al-Moudallal, 2019). It was useful as an analgesic for third molar surgery, but the specimen is small, which is the only article on it.

Ascorbic acid (vitamin C) was administered intravenously used at a dose of $2 \mathrm{~g}$ every 12 hours for three days. In a study with 101 patients (Chaitanya et al, 2019) it showed a similar effectiveness as aceclofenac in the dosage of $100 \mathrm{mg}$ orally. Despite this relative effectiveness, there is only one study evaluating analgesia from vitamin C. One of the disadvantages of this drug is intravenous dosing every 12 hours for three days, which is much more uncomfortable than taking an oral drug.

Other articles have also evaluated alternative drugs with significant success in controlling pain in the postoperative period of the third molars, including using patches containing $14 \mathrm{mg}$ of nicotine (Landim et al, 2020), using $0.8 \%$ hyaluronic acid in gel (Yilmaz et al 2017), and using mouthwash green tea (Eshghpour et al, 2013). While these are unique articles that rated these drugs, they are well science-based and have a minimal risk of bias. However, due to the scarce publication, the effectiveness of these drugs cannot yet be confirmed. Future studies are needed to evaluate its effectiveness. 
Curcumin was only rated in one article (Maulina et al, 2018) and has an elevated risk of bias, and it is heavily criticized in another article (Brignardello-Petersen, 2019). Although it was effective in treating postoperative pain, the control group was not managed efficiently as it received only one capsule of mefenamic acid compared to two capsules of curcumin. The study looked at curcumin in relation to mefenamic acid, an anti-inflammatory agente that is not as common in treating pain after extraction. A comparison with some drugs already established in the literature for this indication such as sodium diclofenac, ibuprofen, or dexamethasone would be possible. Despite its effectiveness, curcumin cannot yet be seen as a valid alternative for controlling postoperative pain.

Other drugs have also presented few publications and yet poor efficacy of drugs normally used for postoperative third molar analgesia such as intra-alveolar melatonin (Cobo-Vázquez ET AL, 2014), which does not raise promising expectations.

\section{Other therapies}

In a study with 45 patients, the transcutaneous electrical nerve stimulation was investigated (Çebi, 2019). The patients underwent third molar extraction and received flurbiprofen $100 \mathrm{mg}$ and amoxicillin $625 \mathrm{mg}$ twice daily for five days. In the second operation, they received the same medication and TENS stimulation ( $50 \mathrm{~Hz}$ frequency, short pulse duration of 100 microseconds) for 15 minutes a day for five days. The use of TENS has proven to be very efficient in postoperative analgesia. Since all patients took analgesics after all extractions, there is no tangible way of assessing the actual effectiveness of TENS. Study at elevated risk of bias.

Another randomized split-mouth single-blind study investigated the effectiveness of TENS in controlling pain after surgery on the third molar. It concluded that this therapy is a useful tool for managing pain because it reduces the number of analgesics that patients must use (Oteri et al, 2018). The sample in this study was small, 32 patients, but the patients did not receive any pain reliever medication other than one that They needed in the postoperative period

\section{Conclusion}

Bromelain is effective in analgesia after third molar surgery, but the same is not true of other proteolytic enzymes such as serratiopeptidase and trypsin. Kinesio tapes are not only effective for pain, but also for trismus and postoperative edema. Some drugs and therapies such as Manuka honey, intra-alveolar hyaluronic acid, and nicotine patches, although with few publications on the subject, have shown promising efficacy that has yet to be proven. Anticonvulsants such as pregabalin are effective but have an elevated risk of side effects. Other therapies such as ascorbic acid injections, TENS, and platelet concentrates may have analgesic efficacy but need to be further investigated and their use standardized. Some unconventional therapies like curcumin, melatonin have not shown any effectiveness.

\section{References}

Afat İ., Akdoğan E.T., Gönül O. (2018). Effects of Leukocyte- and Platelet-Rich Fibrin Alone and Combined With Hyaluronic Acid on Pain, Edema, and Trismus After Surgical Extraction of Impacted Mandibular Third Molars. J Oral Maxillofac Surg. 76(5):926-32.

Al-Khanati N.M. \& Al-Moudallal Y. (2019). Effect of Intrasocket Application of Manuka Honey on Postsurgical Pain of Impacted Mandibular Third Molars Surgery: Split-Mouth Randomized Controlled Trial. J Maxillofac Oral Surg. 18(1):147-52.

Artioli D.P. \& Bertolini G.R.F. (2014). Kinesio taping: application and results on pain: systematic review. Fisioter. Pesquisa. 21 (1): $94-99$.

Asutay F., Yolcu Ü., Geçör O., Acar A.H., Öztürk S.A., Malkoç S. (2017). An evaluation of effects of platelet-rich-fibrin on postoperative morbidities after lower third molar surgery. Niger J Clin Pract. 20(12):1531-6.

Bormann K.H., Weber K., Kloppenburg H., Staude P., Koch A., Meiser P., et al (2016). Perioperative Bromelain Therapy after Wisdom Teeth Extraction - A Randomized, Placebo-Controlled, Double-Blinded, Three-Armed, Cross-Over Dose-Finding Study. Phytother Res. 30(12):2012-9.

Brignardello-Petersen R. (2019). Curcumin probably does not reduce pain importantly after impacted mandibular third-molar surgery compared with mefenamic 
acid. J Am Dent Assoc. 150(1): e 7.

Caymaz M.G., Uyanik L.O. (2019). Comparison of the effect of advanced platelet-rich fibrin and leukocyte- and platelet-rich fibrin on outcomes after removal of impacted mandibular third molar: A randomized split-mouth study. Niger J Clin Pract. 22(4):546-52.

Çebi A.T. (2019). Effects of transcutaneous electrical nerve stimulation on pain after impacted third molar surgery. Med Oral Patol Oral Cir Bucal. 24(3): e 404e8.

Célio-Mariano R., de Melo W.M., Carneiro-Avelino C. (2012). Comparative radiographic evaluation of alveolar bone healing associated with autologous plateletrich plasma after impacted mandibular third molar surgery. J Oral Maxillofac Surg. 70(1):19-24.

Chaitanya N.C., Badam R., Siva Prasad Reddy G., Alwala A., Srinivas P., Saawarn N., et al (2019). Analgesic effect of intravenous ascorbic acid versus acelcofenac post-transalveolar extraction: a case-control study. J Popul Ther Clin Pharmacol. 26(2): e 43-e52.

Cheung C.W., Choi W.S., Leung Y.Y., Lui F., Ng J.K., Hei-Ho A.M., et al (2012). A double-blind randomized crossover study to evaluate the timing of pregabalin for third molar surgery under local anesthesia. J Oral Maxillofac Surg. 70(1):25-30.

Cobo-Vázquez C., Fernández-Tresguerres I., Ortega-Aranegui R., López-Quiles J. (2014). Effects of local melatonin application on post-extraction sockets after third molar surgery. A pilot study. Med Oral Patol Oral Cir Bucal. 19(6): e628-33.

da Rocha Heras A.C.T., de Oliveira D.M.S., Guskuma M.H., de Araújo M.C., Fernandes K.B.P., da Silva Junior R.A., et al (2020). Kinesio taping use to reduce pain and edema after third molar extraction surgery: A randomized controlled split-mouth study. J Craniomaxillofac Surg. 48(2):127-31.

Daugela P., Grimuta V., Sakavicius D., Jonaitis J., Juodzbalys G. (2018). Influence of leukocyte- and platelet-rich fibrin (L-PRF) on the outcomes of impacted mandibular third molar removal surgery: A split-mouth randomized clinical trial. Quintessence Int. 49(5):377-88.

de la Barrera-Núñez M.C., Yáñez-Vico R.M., Batista-Cruzado A., Heurtebise-Saavedra J.M., Castillo-de Oyagüe R., Torres-Lagares D. (2014). Prospective double-blind clinical trial evaluating the effectiveness of Bromelain in the third molar extraction postoperative period. Med Oral Patol Oral Cir Bucal. 19(2): e157-62.

Degirmenci A. \& Yalcin E. (2019). The effect of pregabalin and ibuprofen combination for pain after third molar surgery. Niger J Clin Pract. 22(4):503-10.

Eshghpour M., Mortazavi H., Mohammadzadeh Rezaei N., Nejat A. (2013). Effectiveness of green tea mouthwash in postoperative pain control following surgical removal of impacted third molars: double blind randomized clinical trial. Daru. 21(1):59.

Estrela, C. (2018). Metodologia Científica: Ciência, Ensino, Pesquisa. Editora Artes Médicas.

Gandhewar T., Andrade N.N., Aggarwal N., Choradia S., Mathai P.C., Nerurkar S. (2020). The effects of systemic proteolytic enzyme therapy on pain and swelling in third molar surgery equal to diclofenac therapy: a prospective randomized double blinded clinical trial. Oral Maxillofac Surg. 24(4):461-8.

Ghensi P., Cucchi A., Creminelli L., Tomasi C., Zavan B., Maiorana C. (2017). Effect of Oral Administration of Bromelain on Postoperative Discomfort After Third Molar Surgery. J Craniofac Surg. 28(2): e 191-e7.

Gözlüklü Ö., Ulu M., Gözlüklü H., Yilmaz N. (2020) Comparison of Different Kinesio Taping Techniques After Third Molar Surgery. J Oral Maxillofac Surg. 78(5):695-704.

Isola G., Matarese M., Ramaglia L., Iorio-Siciliano V., Cordasco G., Matarese G. (2019). Efficacy of a drug composed of herbal extracts on postoperative discomfort after surgical removal of impacted mandibular third molar: a randomized, triple-blind, controlled clinical trial. Clin Oral Investig. 23(5):2443-53.

Kapse S., Surana S., Satish M., Hussain S.E., Vyas S., Thakur D. (2019). Autologous platelet-rich fibrin: can it secure a better healing? Oral Surg Oral Med Oral Pathol Oral Radiol. 127(1):8-18.

Kase K., Wallis J., Kase T. (2003). Clinical therapeutic application of the Kinesio taping method. Tokyo, Japan: Ken Ikai Co Ltd.

Kumar N., Prasad K., Ramanujam L. K. R., Dexith J., Chauhan A. (2015). Evaluation of treatment outcome after impacted mandibular third molar surgery with the use of autologous platelet-rich fibrin: a randomized controlled clinical study. J Oral Maxillofac Surg. 73(6):1042-9.

Landim F.S., Laureano Filho J.R., Nascimento J., do Egito Vasconcelos B.C. (2020). Effectiveness of nicotine patch for the control of pain, oedema, and trismus following third molar surgery: a randomized clinical trial. Int J Oral Maxillofac Surg. 49(11):1508-17.

Majid O.W. \& Al-Mashhadani B.A. (2014). Perioperative bromelain reduces pain and swelling and improves quality of life measures after mandibular third molar surgery: a randomized, double-blind, placebo-controlled clinical trial. J Oral Maxillofac Surg. 72(6):1043-8.

Maulina T., Diana H., Cahyanto A., Amaliya A. (2018). The efficacy of curcumin in managing acute inflammation pain on the post-surgical removal of impacted third molars patients: A randomised controlled trial. J Oral Rehabil. 45(9):677-83.

Maurer H.R. (2001). Bromelain: biochemistry, pharmacology, and medical use. Cell Mol Life Sci. 58(9):1234-45

Modanloo H., Eftekharian H., Arabiun H. (2018). Postoperative Pain Management after Impacted Third Molar Surgery with Preoperative Oral Lamotrigine, a Randomized, Double-blind, Placebo-Controlled Trial. J Dent (Shiraz). 19(3):189-96.

Murugesan K., Sreekumar K., Sabapathy B. (2012). Comparison of the roles of serratiopeptidase and dexamethasone in the control of inflammation and trismus following impacted third molar surgery. Indian J Dent Res. 23(6):709-13.

Obossou E.K., Shikamoto Y., Hoshino Y., Kohno H., Ishibasi Y., Kozasa T., et al (2021). Effect of manuka honey on human immunodeficiency virus type 1 
Research, Society and Development, v. 10, n. 14, e3621014221485, 2021

(CC BY 4.0) | ISSN 2525-3409 | DOI: http://dx.doi.org/10.33448/rsd-v10i14.21485

reverse transcriptase activity. Nat Prod Res.1-6.

Ogundipe O.K., Ugboko V.I., Owotade F.J., Paul-Odo B., Afariogun A.B. (2012). Preparation of platelet-rich plasma from small volume of whole blood - a simplified approach. Niger Postgrad Med J. 19(3):133-6.

Olmedo-Gaya M.V., Manzano-Moreno F.J., Galvez-Mateos R., González-Rodriguez M.P., Talero-Sevilla C., Vallecillo-Capilla M. (2016). Oral pregabalin for postoperative pain relief after third molar extraction: a randomized controlled clinical trial. Clin Oral Investig. 20(7):1819-26.

Ordesi P., Pisoni L., Nannei P., Macchi M., Borloni R., Siervo S. (2014). Therapeutic efficacy of bromelain in impacted third molar surgery: a randomized controlled clinical study. Quintessence Int. 45(8):679-84.

Oteri G., Marcianò A., Cervino G., Peditto M. (2018). Impact of electro-neuro-feedback on postoperative outcome of impacted lower third molar surgery. Eur J Dent. 12(1):77-88.

Oyama T., Nishimoto S., Tsugawa T., Shimizu F. (2004). Efficacy of platelet-rich plasma in alveolar bone grafting. J Oral Maxillofac Surg. 62(5):555-8.

Ozgul O., Senses F., Er N., Tekin U., Tuz H.H., Alkan A., et al (2015). Efficacy of platelet rich fibrin in the reduction of the pain and swelling after impacted third molar surgery: randomized multicenter split-mouth clinical trial. Head Face Med. 11:37.

Ritto F.G., Pimentel T., Canellas J.V.S., Junger B., Cruz M., Medeiros P.J. (2019). Randomized double-blind clinical trial evaluation of bone healing after third molar surgery with the use of leukocyte- and platelet-rich fibrin. Int J Oral Maxillofac Surg. 48(8):1088-93.

Tatli U., Benlidayi I.C., Salimov F., Guzel R. (2020). Effectiveness of kinesio taping on postoperative morbidity after impacted mandibular third molar surgery: a prospective, randomized, placebo-controlled clinical study. J Appl Oral Sci. 28: e 20200159.

Torul D., Omezli M.M., Kahveci K. (2020). Evaluation of the effects of concentrated growth factors or advanced platelet rich-fibrin on postoperative pain, edema, and trismus following lower third molar removal: A randomized controlled clinical trial. J Stomatol Oral Maxillofac Surg. 121(6):646-51.

Yilmaz N., Demirtas N., Kazancioglu H.O., Bayer S., Acar A.H., Mihmanli A. (2017). The efficacy of hyaluronic acid in postextraction sockets of impacted third molars: A pilot study. Niger J Clin Pract.2 0(12):1626-31.

Yüce E. \& Kömerik N. (2019). Potential effects of advanced platelet rich fibrin as a wound-healing accelerator in the management of alveolar osteitis: A randomized clinical trial. Niger J Clin Pract. 22(9):1189-95.

Yurttutan M.E. \&Sancak K. T. (2020). The effect of kinesio taping with the web strip technique on pain, edema, and trismus after impacted mandibular third molar surgery. Niger J Clin Pract. 23(9):1260-5.

Zahid T.M. \& Nadershah M. (2019). Effect of Advanced Platelet-rich Fibrin on Wound Healing after Third Molar Extraction: A Split-mouth Randomized Doubleblind Study. J Contemp Dent Pract. 20(10):1164-70 